\title{
Chemical characteristics of grape juices from different cultivar and rootstock combinations
}

\author{
Rita de Cássia Mirela Resende Nassur ${ }^{(1)}$, Giuliano Elias Pereira(2), \\ Juliana Alvarenga Alves ${ }^{(1)}$ and Luiz Carlos de Oliveira Lima ${ }^{(1)}$
}

\begin{abstract}
(1)Universidade Federal de Lavras, Departamento de Ciência dos Alimentos, Caixa Postal 3037, CEP 37200-000 Lavras, MG, Brazil. E-mail: ritarnassur@hotmail.com, juliana_alvarenga@yahoo.com.br, Icolima@dca.ufla.br (2)Embrapa Uva e Vinho, Rodovia BR 428, Km 152, Caixa Postal 23, CEP 56302-970 Petrolina, PE, Brazil. E-mail: giuliano.pereira@embrapa.br
\end{abstract}

\begin{abstract}
The objective of this work was to evaluate the influence of different combinations of grape cultivars and rootstocks on chemical characteristics of grape juices. Six treatments were evaluated, consisting of combinations between the Isabel Precoce and BRS Cora grape cultivars and the 'IAC 766', 'IAC 313', and 'IAC 572' rootstocks. Approximately $10 \mathrm{~L}$ of juice were obtained per treatment. Analyses of color, total soluble solids content, $\mathrm{pH}$, anthocyanins, total phenolics, total sugars, and quantification and identification of biogenic amines by HPLC were performed. Biogenic amines, such as putrescine, cadaverine, spermidine, and spermine, were found in all evaluated cultivars. By principal component analysis (PCA), treatments can be divided into two groups, according to the cultivar. Juices obtained from 'Isabel Precoce' are characterized by higher levels of total sugar content and soluble solids; however, juices from 'BRS Cora' are positively correlated with phenolic content, anthocyanins, and color and acidity parameters. The differences found by PCA for juices from the Isabel Precoce and BRS Cora cultivars indicate that, regardless of the rootstock used, the most important factor in the chemical characterization of juices is the grape cultivar.
\end{abstract}

Index terms: Vitis labrusca, anthocyanins, biogenic amines, phenolics, principal component analysis.

\section{Características químicas de sucos de uva obtidos de diferentes combinações de cultivares e porta-enxertos}

Resumo - O objetivo deste trabalho foi avaliar a influência de diferentes combinações de cultivares de uva e porta-enxertos nas características químicas de sucos de uva. Foram avaliados seis tratamentos, que consistiram de combinações entre as cultivares de uva Isabel Precoce e BRS Cora com os porta-enxertos 'IAC 766', 'IAC 313' e 'IAC 572'. Aproximadamente $10 \mathrm{~L}$ de suco foram obtidos por tratamento. Foram realizadas análises de coloração, teor de sólidos solúveis totais, $\mathrm{pH}$, antocianinas, compostos fenólicos totais, açúcares totais, e quantificação e identificação de aminas biogênicas por HPLC. Aminas biogênicas, tais como putrescina, cadaverina, espermidina e espermina, foram encontradas em todas as cultivares avaliadas. Por meio da análise de componentes principais (PCA), os tratamentos podem ser divididos em dois grupos, de acordo com a cultivar. Sucos obtidos de 'Isabel Precoce' são caracterizados pelos maiores teores de açúcares totais e sólidos solúveis; no entanto, sucos de 'BRS Cora' correlacionam-se positivamente com conteúdo fenólico, antocianinas, e parâmetros de coloração e acidez. As diferenças encontradas por meio da PCA, para sucos das cultivares Isabel Precoce e BRS Cora, indicam que, independentemente do porta-enxerto utilizado, o fator mais importante na caracterização química dos sucos é a cultivar de uva.

Termos para indexação: Vitis labrusca, antocianinas, aminas biogênicas, fenólicos, análise de componentes principais.

\section{Introduction}

Grape (Vitis labrusca L.) juices are consumed worldwide and are considered an important source of phytochemicals, such as anthocyanins, biogenic amines, and polyphenolic compounds (Dani et al., 2007; Burin et al., 2010).
Anthocyanins are pigments that contribute to fruit and juice color, and their content in grape fruit varies largely according to genotype and environmental conditions (Liang et al., 2008); whereas biogenic amines are organic bases with low molecular weight that can be: aliphatic, including putrescine, cadaverine, spermidine, and spermine; heterocyclic, such as 
histamine and tryptamine; or aromatic, comprising tyramine and henylethylamine. The most important biogenic amines that can occur in foods and beverages are histamine, beta-phenylethylamine, tyramine, tryptamine, putrescine, cadaverine, spermine, and spermidine (Naila et al., 2010).

However, the presence of biogenic amines in food products can cause health risks to sensitive individuals. Consumption of food containing high amounts of this substance may cause headaches, nausea, hot flushes, cold sweat, red rash, high or low blood pressure, and digestive problems (Kalac \& Krausova, 2005). The analytical determination of biogenic amines in wines and grape juices is important to provide useful information about these products.

Genetic material is a key factor to determine grape juice quality. In this context, studies have characterized grape genotypes that have potential to produce high quality juice with higher content of phenolic compounds, anthocyanins, total sugars, and reduced presence of biogenic amines.

The objective of this work was to evaluate the influence of different combinations of grape cultivars and rootstocks on chemical characteristics of grape juices.

\section{Materials and Methods}

The grape cultivars assessed were BRS Cora and Isabel Precoce, located in the experimental area of the Bebedouro irrigation project of Embrapa Semiárido, in the municipality of Petrolina, in the state of Pernambuco, Brazil $\left(9^{\circ} 21^{\prime} \mathrm{S}, 40^{\circ} 40^{\prime} \mathrm{W}\right.$, at approximately $350 \mathrm{~m}$ of altitude).

The experimental design was a randomized complete block. The cultivars were grafted onto the 'IAC 766', 'IAC 313', and 'IAC 572' rootstocks. Six treatments were evaluated, consisting of the combination between the Isabel Precoce and BRS Cora cultivars and the 'IAC 766', 'IAC 313', and 'IAC 572' rootstocks.

The plants were installed five years before, grown on a drip-irrigated trellis system, spaced at $3.5 \times 2.0 \mathrm{~m}$. The total cycle, between prune and harvest, was of 105 days for 'Isabel Precoce' and of 111 days for 'BRS Cora'. Fifteen $\mathrm{kg}$ of grapes were harvested per block in the morning at optimal maturity, based on total soluble sugars and total acidity, and were taken to the Laboratório de Enologia of Embrapa Semiárido, where they were placed in cold chambers at $10^{\circ} \mathrm{C}$, for 12 hours, before being processed. The grapes, $15 \mathrm{~kg}$ for each block, were then hand stripped and placed in an experiment container. Juice extraction was accomplished with water vapor during $60 \mathrm{~min}$, at $75-80^{\circ} \mathrm{C}$, obtaining approximately $10 \mathrm{~L}$ of juice per treatment. The juice was sulphited $\left(25 \mathrm{mg} \mathrm{L}^{-1}\right.$ potassium metabisulfite) and pasteurized after bottling in $500 \mathrm{~mL}$ containers with plastic lids with a lock screw.

Total soluble solids were determined in a filtered homogenate using a digital refractometer, model PR-100 (Atago, Tokyo, Japan), with automatic temperature compensation to $25^{\circ} \mathrm{C}$ (Horwitz, 2002). Total sugar determinations, which provide the percentage of glucose, were extracted with $70 \%$ ethanol and determined by the Antrona method (Dische, 1962).

Juice color was measured using a colorimeter, model CR-400 (Konica Minolta Business Solutions U.S.A., Ramsey, NY, USA), with an $8 \mathrm{~mm}$ light path aperture. The instrument was calibrated with a CR-400 standard tile $(\mathrm{Y}=93.5, \mathrm{x}=0.3114, \mathrm{y}=0.3190)$ (Konica Minolta Business Solutions U.S.A., Ramsey, NY, USA) . Juice color results were characterized by: lightness ( $\mathrm{L}^{*}$ ), which ranges from black (0) to white (100); and chromaticity $\left(\mathrm{C}^{*}\right)$, which represents color purity. Juice $\mathrm{pH}$ was determined with a $\mathrm{pH}$ meter, model Tec-3MP (Tecnal Equipamentos para Laboratórios, Piracicaba, SP, Brazil).

Analysis of total anthocyanins was performed following the method of differential $\mathrm{pH}$ (Giusti \& Wrolstad, 2001). A solution with acidified methanol was centrifuged at $2,000 \mathrm{~g}$ for $15 \mathrm{~min}$, at $4^{\circ} \mathrm{C}$, for sample preparation. An aliquot of the supernatant was diluted with buffers of $\mathrm{pH} 1.0$ and 4.5, and determinations were taken at wavelengths of 510 and $700 \mathrm{~nm}$ on a Varian Cary 50 probe spectrophotometer (Varian Medical Systems, Belrose, Australia). The total content of anthocyanins was calculated as cyanidin-3-glucoside.

Phenolic content was determined according to the methodology of Singleton \& Rossi Junior (1965) using the Folin-Ciocalteu reagent. The extraction procedure involved steps of centrifugation, filtration, and rest in order to obtain a better extraction of phenolic compounds. Phenolic content was then determined by a spectrophotometer Varian Cary 50 probe (Varian Medical Systems, Belrose, Australia) at $750 \mathrm{~nm}$, and the absorption values were compared with the standard curve with gallic acid. 
Biogenic amines were determined in the Departmento de Farmácia of Universidade Federal de Minas Gerais, in the state of Minas Gerais, Brazil, where the juices were homogenized, degassed in an ultrasound, centrifuged at $10,000 \mathrm{~g}$, at $4^{\circ} \mathrm{C}$, for $20 \mathrm{~min}$, and filtered through a cellulose hydrophilic membrane filter (HAWP, Millipore, Bedford, MA, USA). The amines were then separated by ion-pair reverse-phase high-performance liquid chromatography (HPLC) (Shimadzu Corporation, Kyoto, Japan) and quantified fluorimetrically after post-column derivatization with o-phthalaldehyde. Liquid chromatography was performed on a LC-10AD system connected to a RF-551 spectrofluorimetric detector at 340 and $445 \mathrm{~nm}$ of excitation and emission, respectively, and to a CBM-10AD controller (Shimadzu Corporation, Kyoto, Japan). A reversed-phase $\mu$ Bondapak C18 column, 300x3.9 mm i.d., $10 \mu \mathrm{m}$, was used with a $\mu$ Bondapak C18 Guard-Pak Insert (Waters, Milford, MA, USA). The mobile phases were: solution of $0.2 \mathrm{~mol} \mathrm{~L}^{-1}$ sodium acetate and $10 \mathrm{mmol} \mathrm{\textrm {L } ^ { - 1 }}$ 1-octanesulfonic acid sodium salt adjusted to $\mathrm{pH} 5.0$ with acetic acid; and acetonitrile. The flow rate was set at $0.8 \mathrm{~mL} \mathrm{~min}^{-1}$, and the gradient was: $13 \mathrm{~min}$ at $11 \%$ acetonitrile, $19 \mathrm{~min}$ at $30 \%$ acetonitrile, $24 \mathrm{~min}$ at $11 \%$ acetonitrile, and $45 \mathrm{~min}$ at $11 \%$ acetonitrile. The post-column derivatization reagent was delivered at

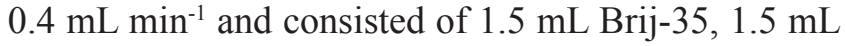
mercaptoethanol, and $0.2 \mathrm{~g}$ o-phthalaldehyde dissolved in a $500 \mathrm{~mL}$ solution of $25 \mathrm{~g}$ boric acid and $22 \mathrm{~g} \mathrm{KOH}$ ( $\mathrm{pH}$ adjusted to 10.5 with $3 \% \mathrm{KOH}$ ). The column and the post-column reaction apparatus were kept at room temperature $\left(22 \pm 1^{\circ} \mathrm{C}\right)$. The identification of amines was performed by comparison of retention times of amines in samples to standard solutions and also by the addition of the suspected amine to the sample. Amine levels were calculated by direct interpolation in the standard curve. No replicates and no statistical analysis were made for quantification of biogenic amines, only quantification by HPLC and assessment with standards were performed.

The study of chemical characteristics of juice was carried out in a completely randomized design, with six treatments and four replicates. Means were compared by Tukey's test, at $5 \%$ probability, except for biogenic amines, in which the values obtained by HPLC were compared to the standard peak. Principal component analysis (PCA) was performed on data of the grape juices. The dataset was autoscaled before analysis. Calculations were performed in the Chemoface software, version 1.4 (Nunes et al., 2012).

\section{Results and Discussion}

The content of soluble solids was significantly greater for the Isabel Precoce cultivar combined with the 'IAC 766' and 'IAC 313' rootstocks (Table 1). Juices made from the combination between 'BRS Cora' and 'IAC 572' showed the highest values of anthocyanin content. For total sugars, 'Isabel Precoce' combined with 'IAC 313' presented higher contents than the other combinations. 'Isabel Precoce' is originally from a spontaneous somatic mutation of the variety Isabel and it offers good productivity, anticipated maturation, and the same characteristics as the original cultivar (Camargo, 2004).

For color measurements, the lightness $\left(\mathrm{L}^{*}\right)$ of the juices did not differ significantly between the evaluated materials, indicating that it was not affected by the cultivar effect. Chromaticity $\left(\mathrm{C}^{*}\right)$ was higher

Table 1. Quality characteristics of grape (Vitis labrusca) juices obtained from the cultivars BRS Cora and Isabel Precoce grown on the 'IAC 766', 'IAC 313', and 'IAC 572' rootstocks ${ }^{(1)}$

\begin{tabular}{|c|c|c|c|c|c|c|c|}
\hline Cultivar/rootstock & $\begin{array}{c}\text { Soluble solid } \\
(\%)\end{array}$ & $\mathrm{C}^{*}$ & $\mathrm{~L}^{*}$ & $\mathrm{pH}$ & $\begin{array}{l}\text { Anthocyanins } \\
\left(\mathrm{mg} \mathrm{L}^{-1}\right)\end{array}$ & $\begin{array}{l}\text { Phenolic content } \\
\left(\mathrm{mg} \mathrm{L}^{-1}\right)\end{array}$ & $\begin{array}{c}\text { Total sugars } \\
\left(\mathrm{g} \mathrm{L}^{-1}\right)\end{array}$ \\
\hline BRS Cora/ IAC 766 & $14.60 \mathrm{~b}$ & $24.65 b$ & $18.38 \mathrm{a}$ & $3.30 \mathrm{c}$ & $22.80 \mathrm{~d}$ & $1.25 \mathrm{~b}$ & $27.31 \mathrm{~b}$ \\
\hline BRS Cora/ IAC 313 & $14.10 \mathrm{~b}$ & $27.04 \mathrm{ab}$ & $19.86 \mathrm{a}$ & $3.40 \mathrm{~b}$ & $108.17 b$ & $1.50 \mathrm{a}$ & $26.74 \mathrm{c}$ \\
\hline BRS Cora/ IAC 572 & $14.36 \mathrm{~b}$ & $32.81 \mathrm{a}$ & $22.54 \mathrm{a}$ & $3.50 \mathrm{a}$ & $168.34 \mathrm{a}$ & $1.51 \mathrm{a}$ & $19.98 \mathrm{~d}$ \\
\hline Isabel Precoce/ IAC 766 & $15.66 \mathrm{a}$ & $27.36 \mathrm{ab}$ & $17.48 \mathrm{a}$ & $3.50 \mathrm{a}$ & $43.22 \mathrm{c}$ & $1.05 \mathrm{c}$ & $23.81 \mathrm{c}$ \\
\hline Isabel Precoce/ IAC 313 & $15.83 \mathrm{a}$ & $16.88 \mathrm{~b}$ & $14.48 \mathrm{a}$ & $3.40 \mathrm{~b}$ & $35.12 \mathrm{c}$ & $0.93 c$ & $30.85 a$ \\
\hline Isabel Precoce/ IAC 572 & $14.56 \mathrm{~b}$ & $20.65 \mathrm{ab}$ & $16.46 \mathrm{a}$ & $3.30 \mathrm{c}$ & $43.53 \mathrm{c}$ & $0.92 \mathrm{c}$ & $24.19 \mathrm{c}$ \\
\hline $\mathrm{CV}(\%)$ & 1.28 & 8.98 & 13.58 & 0.00 & 4.36 & 3.83 & 3.11 \\
\hline
\end{tabular}

${ }^{(1)}$ Means followed by equal letters in the columns do not differ by Tukey's test, at $5 \%$ probability. 
for juice from: 'BRS Cora' with 'IAC 572', 'Isabel Precoce' with 'IAC 766' and 'IAC 572', and 'BRS Cora' with 'IAC 313'; this value indicates higher color intensity. The 'BRS Cora' hybrid variety is used to improve the color of juices when required, and the use of a proportion of $15-20 \%$ in the juice formulation is recommended (Camargo et al., 2005).

Juices from 'Isabel Precoce' combined with 'IAC 572' and from 'BRS Cora' with 'IAC 766' were the ones with the lowest $\mathrm{pH}$, and those from 'BRS Cora' combined with 'IAC 572' and 'IAC 313' presented the highest phenolic content and were the first material to show a higher anthocyanin content.

The anthocyanins present in the juice varied greatly depending on the used cultivar and rootstock. Verdana et al. (2008) observed contents of 100.5 $\mathrm{mg} \mathrm{L}^{-1}$ for juices obtained from the Isabel Precoce cultivar. According to Malacrida \& Mota (2005), anthocyanins concentration in grape juices range from 11.70 to $668 \mathrm{mg} \mathrm{L}^{-1}$. The Isabel Precoce cultivar, regardless of the used rootstock, produced juices with no differences for anthocyanin content.

Rootstock strength can strongly influence the phenolic composition and the levels of phenolic compounds of grapes, and, consequently, of grape juices too (Reynier, 2007). The contents of phenolic compounds in the present work varied from 0.92 to $1.51 \mathrm{~g} \mathrm{~L}^{-1}$. Malacrida \& Mota (2005) found content of total phenolic compounds on grape juices of $1.43 \mathrm{~g} \mathrm{~L}^{-1}$, whereas Verdana et al. (2008) reported $1.88 \mathrm{~g} \mathrm{~L}^{-1}$ of phenolics on grape juices from the Isabel Precoce cultivar. The combination between the 'IAC 572' rootstock and the BRS Cora cultivar presented, on average, one of the highest concentrations of phenolic compounds, anthocyanins, chromaticity, $\mathrm{pH}$, and juice lightness (Table 1).

Four biogenic amines - putrescine, cadaverine, spermidine, and spermine - were detected in all evaluated grape juices (Table 2). The highest levels of biogenic amines were observed when putrescine and spermidine were assessed, varying from 0.97 to $2.67 \mu \mathrm{g} \mathrm{mL}^{-1}$ and from 1.66 to 2.69 , respectively. Cunha et al. (2011) observed the presence of biogenic amines in grape juice samples. According to these authors, putrescine was the most abundant, ranging from 1.06 to $7.25 \mathrm{mg} \mathrm{L}^{-1}$, with an average level of $3.02 \mathrm{mg} \mathrm{L}^{-1}$, usually accounting for around $50 \%$ of the total amine content. It was followed by ethylamine, methylamine, 2-phenylethylamine, histamine, and tyramine.

The presence of putrescine in grape juices, as well as cadaverine, spermine, and spermidine, was also reported by Bauza et al. (1995) and Sass-Kiss et al. (2000). Bover-Cid et al. (2006) found the presence of putrescine and cadaverine in 16 samples of Cabernet Sauvignon grape juices, with an average of 6.81 and $1.16 \mathrm{mg} \mathrm{kg}^{-1}$, respectively. Del Prete et al. (2009) obtained an average level of $11.23 \mathrm{mg} \mathrm{L}^{-1}$ of putrescine for 14 grape juices, representative of seven different cultivars from the 2004 and 2005 vintages.

A distinction among the juices was observed according to PCA scores: principal component 1 (PC1) explained close to $60 \%$ of the variance and distributed juices from 'Isabel Precoce' grapes to the left and from 'BRS Cora' to the right of the score plot (Figure 1). Juices from 'BRS Cora' grapes presented elevated content of cadaverine, spermine, phenolics, and anthocyanins, in addition to high values for color ( $\mathrm{L}^{*}$ and $\mathrm{C}^{*}$ ). Juices from 'Isabel Precoce' grapes had a tendency of showing higher values for putrescine, spermidine, and

Table 2. Biogenic amines of grape (Vitis labrusca) juices obtained from the cultivars BRS Cora and Isabel Precoce grown on the 'IAC 766', 'IAC 313', and 'IAC 572' rootstocks ${ }^{(1)}$.

\begin{tabular}{|c|c|c|c|c|}
\hline Juice & Putrescine & Cadaverine & Spermidine & Spermine \\
\hline & & 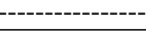 & 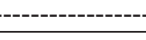 & ------ \\
\hline 'Isabel Precoce' + 'IAC 766' & 2.25 & 0.13 & 2.76 & 0.58 \\
\hline 'Isabel Precoce' + 'IAC 313' & 2.67 & 0.16 & 2.69 & 0.85 \\
\hline 'Isabel Precoce' + 'IAC 572' & 1.79 & 0.18 & 2.57 & 0.39 \\
\hline 'BRS Cora' + 'IAC 766' & 1.22 & 0.38 & 1.66 & 0.55 \\
\hline 'BRS Cora' + 'IAC 313' & 0.97 & 0.30 & 1.84 & 1.10 \\
\hline 'BRS Cora' + 'IAC 572' & 0.61 & 0.22 & 1.98 & 0.71 \\
\hline
\end{tabular}

${ }^{(1)}$ No replicates and no statistical analysis were made for quantification of biogenic amines, only quantification by HPLC and assessment with standards were performed. 
soluble solids. The characteristics $\mathrm{pH}$ and total sugars had lower relevance to the discrimination of the juices by PCA. Regardless of the used rootstock, the most important factor to characterize the juices was the grape cultivar.

The juice from 'BRS Cora' combined with 'IAC 572 ' presented desirable quality characteristics and a positive correlation for chroma value and anthocyanin content. A high chroma value indicates a highly saturated and intense color of the juice, whereas a low value, such as the one observed in juices from 'Isabel Precoce' and 'IAC 313', has a negative correlation with these color characteristics. However, the juice from 'BRS Cora' combined with 'IAC 572' showed a lower content of total sugars, which is a disadvantage for grape juices. The elevated content of anthocyanin in juices from 'BRS Cora' combined with 'IAC 313' and 'IAC 572' can explain the high contribution to total phenolic content.



Figure 1. Principal component analysis of grape (Vitis labrusca) juices and their characteristics. PHEN, phenolic compounds; L, lightness; C, chromaticity; and SS, soluble solids. Cultivars and rootstocks: 1, 'Isabel Precoce' and 'IAC 766'; 2, 'BRS Cora' and 'IAC 313'; 3, 'Isabel Precoce' and 'IAC 572'; 4, 'BRS Cora' and 'IAC 572'; 5, 'Isabel Precoce'and 'IAC 313'; and 6, 'BRS Cora' and 'IAC 766'.

\section{Conclusions}

1. Cultivars influence the chemical characteristics of grape (Vitis labrusca) juices, regardless of the rootstock combined to them.

2. Grapes from 'BRS Cora' present elevated content of cadaverine, spermine, phenolics, and anthocyanins, in addition to high values for color.

3. 'BRS Cora' combined with the 'IAC 313' and 'IAC 572' rootstocks produces juices with the highest phenolic content, and 'BRS Cora' combined with 'IAC 572 ', juices with the highest levels of anthocyanins and the lowest levels of total sugars.

4. Four biogenic amines are present in all juices: putrescine, spermidine, cadaverine, and spermine.

\section{Acknowledgement}

To Coordenação de Aperfeiçoamento de Pessoal de Nível Superior (Capes), to Conselho Nacional de Desenvolvimento Científico e Tecnológico (CNPq), to Fundação de Amparo à Pesquisa do Estado de Minas Gerais (Fapemig), to Empresa Brasileira de Pesquisa Agropecuária (Embrapa), and to Empresa de Pesquisa Agropecuária de Minas Gerais (Epamig), for financial support.

\section{References}

BAUZA, T.; BLAISE, A.; MESTRES, J.P.; TEISSEDRE, P.L.; DAUMAS, F.; CABANIS, J.C. Teneurs en amines biogènes et facteurs de leurs variations dans les vins des côtes du Rhône, de la vallée du Rhone et de Provence. Sciences des Aliments, v.15, p.367-380, 1995.

BOVER-CID, S.; IQUIERDO-PULIDO, M.; MARINÉ-FONT, A.; VIDAL-CAROU, M.C. Biogenic mono-, di- and polyamine contents in Spanish wines and influence of a limited irrigation. Food Chemistry, v.96, p.43-47, 2006. DOI: 10.1016/j. foodchem.2005.01.054.

BURIN, V.M.; FALCÃO, L.D.; GONZAGA, L.V.; FETT, R.; ROSIER, J.P.; BORDIGNON-LUIZ, M.T. Colour, phenolic content and antioxidant activity of grape juice. Ciência e Tecnologia de Alimentos, v.30, p.1027-1032, 2010. DOI: 10.1590/ S0101-20612010000400030.

CAMARGO, U.A. 'Isabel Precoce': alternativa para a vitivinicultura brasileira. Bento Gonçalves: Embrapa Uva e Vinho, 2004. 4p. (Embrapa Uva e Vinho. Comunicado técnico, 54).

CAMARGO, U.A.; MAIA, J.D.G.; NACHTIGAL, J.C. BRS Violeta: nova cultivar de uva para suco e vinho de mesa. Bento Gonçalves: Embrapa Uva e Vinho, 2005. 8p. (Embrapa Uva e Vinho. Comunicado técnico, 63). 
CUNHA, S.C.; FARIA, M.A.; FERNANDES, J.O. Gas chromatography-mass spectrometry assessment of amines in Port wine and grape juice after fast chloroformate extraction/ derivatization. Journal of Agricultural and Food Chemistry, v.59, p.8742-8753, 2011. DOI: 10.1021/jf201379x.

DANI, C.; OLIBONI, L.S.; VANDERLINDE, R.; BONATTO, D.; SALVADOR, M.; HENRIQUES, J.A.P. Phenolic content and antioxidant activities of white and purple juices manufactured with organically- or conventionally-produced grapes. Food and Chemical Toxicology, v.45, p.2574-2580, 2007. DOI: 10.1016/j. fct.2007.06.022.

DEL PRETE, V.; COSTANTINI, A.; CECCHINI, F.; MORASSUT, M.; GARCIA-MORUNOA, E. Occurrence of biogenic amines in wine: the role of grapes. Food Chemistry, v.112, p.474-481, 2009. DOI: 10.1016/j.foodchem.2008.05.102.

DISCHE, Z. General color reactions. In: WHISTLER, R.L.; WOLFRAM, M.L. (Ed.). Carbohydrate chemistry. New York: Academic Press, 1962. v.1, p.477-512.

GIUSTII, M.M.; WROLSTAD, R.E. Characterization and measurement of Anthocyanins by UV-visible spectroscopy. In: WROLSTAD, R.E. (Ed.). Current protocols in food analytical chemistry. New York: Wiley, 2001. DOI: 10.1002/0471142913. faf0102s00.

HORWITZ, W. Official methods of analysis of the Association of Official Analytical Chemists. $17^{\text {th }}$ ed. Washington: AOAC International, 2002. 1115p.

KALAC, P.; KRAUSOVA, P. A review of dietary polyamines: formation, implications for growth and health and occurrence in foods. Food Chemistry, v.90, p.219-230, 2005. DOI: 10.1016/j. foodchem.2004.03.044.
LIANG, Z.; WU, B.; FAN, P.; YANG, C.; DUAN, W.; ZHENG, X.; LIU, C.; LI, S. Anthocyanin composition and content in grape berry skin in Vitis germplasm. Food Chemistry, v.111, p.837-844, 2008. DOI: 10.1016/j.foodchem.2008.04.069.

MALACRIDA, C.R.; MOTTA, S. da. Compostos fenólicos totais e antocianinas em sucos de uva. Ciência e Tecnologia de Alimentos, v.25, p.659-664, 2005. DOI: 10.1590/ S0101-20612005000400006.

NAILA, A.; FLINT, S.; FLETCHER, G.; BREMER, P.; MEERDINK, G. Control of biogenic amines in food - existing and emerging approaches. Journal of Food Science, v.75, p.139-150, 2010. DOI: 10.1111/j.1750-3841.2010.01774.x.

NUNES, C.A.; FREITAS, M.P.; PINHEIRO, A.C.M.; BASTOS, S.C. Chemoface: a novel free user-friendly interface for chemometrics. Journal of the Brazilian Chemical Society, v.23, p.2003-2010, 2012. DOI: 10.1590/S0103-50532012005000073.

REYNIER, A. Manuel de viticulture. $10^{\text {th }} \mathrm{ed}$. Paris: Lavoisier, 2007. 532p.

SASS-KISS, A.; SZERDAHELYI, E.; HAJÓS, G. Study of biologically active amines in grapes and wines by HPLC. Chromatographia, v.51, p.316-320, 2000. DOI: $10.1007 /$ BF02492826.

SINGLETON, V.L.; ROSSI JUNIOR, J.A. Colorimetry of total phenolics with phosphomolybdic-phosphotungstic acid reagents. American Journal of Enology and Viticulture, v.16, p.144-158, 1965.

VEDANA, M.I.S.; ZIEMER, C.; MIGUEL, O.G.; PORTELLA, A.C.; CANDIDO, L.M.B. Efeito do processamento na atividade antioxidante de uva. Alimentos e Nutrição, v.19, p.159-165, 2008.

Recebido em 14 de fevereiro de 2014 e aprovado em 27 de junho de 2014 